\title{
Review of Spare Rib Archive 1972 to 1980
}

\section{Shirley Doulière}

\section{OpenEdition}

\section{Journals}

Electronic version

URL: https://journals.openedition.org/rfcb/1739

DOI: $10.4000 /$ rfcb.1739

ISSN: 2429-4373

\section{Publisher}

CRECIB - Centre de recherche et d'études en civilisation britannique

\section{Electronic reference}

Shirley Doulière, "Review of Spare Rib Archive 1972 to 1980", Revue Française de Civilisation Britannique [Online], XXII- Hors série | 2017, Online since 31 December 2017, connection on 04 March 2022. URL: http://journals.openedition.org/rfcb/1739; DOI: https://doi.org/10.4000/rfcb.1739

This text was automatically generated on 4 March 2022.

Revue française de civilisation britannique est mis à disposition selon les termes de la licence Creative Commons Attribution - Pas d'Utilisation Commerciale - Pas de Modification 4.0 International. 


\title{
Review of Spare Rib Archive 1972 to 1980
}

\author{
Shirley Doulière
}

\section{REFERENCES}

British Library Archives https://www.bl.uk/spare-rib

1 The British Library has recently digitized the entire collection of Spare Rib, the iconic feminist magazine created in the early 1970's. Many publications were already available but it is very rare to have access to an openly partisan magazine courtesy of a national library. Being able to use these online archives offers an invaluable insight into the feminist press for researchers in both Gender Studies and History.

2 In the wake of the rise of the British Women's Liberation Movement (BWLM), Spare Rib was launched by Marsha Rowe and Rosie Boycott to offer a magazine that could provide answers to the questions and challenges women were faced with. Though it was tagged as being too "anti men" and "depressing" by some readers, the magazine's popularity grew and it published 239 issues from 1972 to 1993. The aim was clearly stated in the first issue: "to reflect the questions, ideas and hope that is growing out of our awareness of ourselves not as a 'bunch of women' but as individuals in our own rights" thus moving away from the image of the "Tupperware party" attached to the consciousness raising groups. Because it tackled the burning issues of the 70's, Spare Rib is not only a mirror of its society but also a reminder of how far women have come in their struggle.

3 The various topics addressed revolve mainly around female empowerment and do not differ very much from modern day feminist preoccupations: the question of marriage and property gave rise to an article denouncing the inequities in divorce. Women often contributed to household spending but without having their name on anything, and, as such, divorcees or widows could find themselves penniless. In the early issues could be found many articles meant to teach women to be self sufficient: how to fix things 
around the house and the car, how to use self defense against would-be rapists. One could also find DIY tips or patterns for knitting, ideas for school snacks, a children's page, and recipes. However, some of these elements were later discontinued in favor of more political topics. Among them were the right to a fair divorce, easier access to loans in order to own property, the right to have a bank account without one's husband's permission, as well as stories of rape going unpunished with the collusion of the police. "In our own write", the letters section, dealt with issues which remain relevant today: women being pressured to look good, the pressure to be everything at the same time- mother, lover, mother, housekeeper- and the trials of everyday sexism. Contributions included an article penned by a male judge of beauty pageants: "The Dark Cruel World of Beauty Contests".

4 The early magazines seemed very "London-oriented" and keen to help white working women. From 1972 to 1974, the magazine was mostly concerned with protecting wives from their husbands, especially in cases of divorce, with articles such as "Could your husband leave you bankrupt?" or writings dealing with protecting oneself from physical abuse. Along with the concern over money, it also dealt with the question of child custody and several articles were published over the years on "Do-It-Yourself divorce", giving women as much legal advice as possible. With the Equal Pay Act passed in 1970, there were a few pieces about the salary gap and the tendency to hire woman only as secretaries when they were more than able to perform other tasks.

5 Two topics recurrent over the decade were shown when the question of censorship of an article by Germaine Greer on abortion was discussed, tackling both the issue of abortion and the fact that it was still considered taboo to discuss it. And also, there was a piece encouraging women to join industrial Unions. An article raises the problem that, although women have better access to education, they are still under-represented in the work force, another that the quota of female students in medical schools is only $20 \%$. On several occasions, Spare Rib published articles demanding equal pay for equal work, and addressed the problems of gendered education, denouncing for example the fact that little girls in London were taken to the Victoria and Albert Museum when boys would be taken to the Science Museum.

6 Unlike other publications of the time, Spare Rib talked freely and regularly about sexuality: Orgasm ("How to have one"), bisexuality, homosexuality, and contraception. In addition to dealing with sexuality and the female body per se, some articles dealt with the political aspect of discovering women's history, sexuality and body, with pieces on Betty Friedan's The Feminine Mystique, and Kate Millet's Sexual Politics.

7 The environment question was not ignored as Pat Bar, a specialist of female explorers and quite the globe trotter herself, started an ongoing ecology series.

8 From the very beginning, the editors included a "Women's Lives in Other Countries" series, which lasted right until the end of the magazine. The articles revolved around women living, for the most part, in developing countries, and depicted the political, sexual and health challenges they were facing. Topics included: the Great Revolution in China, the Revolution in Cuba (through a portrait of Tanya, a German citizen who fought alongside Che Guevara), widow-burning in India, an interview with a member of the Vietnamese provisional government, forced sterilisation in Puerto Rico, women farmers in Zambia, feminism in the USA and the women's rising in Iran.

9 This came at a time when women were concerned with developing a global sisterhood. The $21^{\text {st }}$ century reader does cringe slightly at the dichotomy between developing 
countries that are used as example of places needing help and the US which is clearly the nation to look up to and learn from. It also seems like a dominant posture of pitying the developing countries and reassuring oneself that, as bad as women's lives are in the UK, at least they are neither Indian nor Puerto Rican.

10 The issues of the years 1974-1975 were marked by the Miners' strike of 1974 with many of the articles concerned with unions, strikes, working class heroes, the London schools and hospital crisis, and the union's refusal to take women fully into account, as discussed in the cover article "Union Officials betrayal of Women". 1974 also saw its first cover featuring a Black woman, the only one for 1974, though there was another one in 1975, showing a woman with her mixed-race child.

11 The female body was the centre of attention with articles on masturbation, gynecology, hysterectomy, how to advocate abortion, childbirth, post natal depression, and managing pain. This mirrored the worries of women as most readers' letters dealt with abortion and the body. With the provocative cover "RAPE: who cares? ", Spare Rib pushed the envelope further on the need to treat rape as a serious crime and put an end to blaming women for dressing too scantily and therefore "deserving" to be raped. The magazine had never treated this topic and it opened onto more pieces in the following years. The year 1975 also ended with a call to urge women to achieve social progress by trusting each other, and warning them that sisterhood should not be taken for granted with such articles as "women who trample on women's lib".

12 The articles in years 1976-1977 were mostly dedicated to topics such as: self help, compulsive eating, or the emotional and psychological needs of factory workers (as seen by a nurse). Only one article covered the strikes but the issues of 1977 were rife with sense of fighting on both the political front and the physical front with pieces on self defense, women's clinics, the vote, lesbian rebellion, black girls faced with violence at school, and women's punk. The last issue, with two Indian women on the cover, also exposes rising racism in the UK against Asian women and ends a year consumed with social unrest.

The last two years under scrutiny,1978-1979 show a growing concern already hinted at in the last issues with the question of alternative lifestyles, whether in terms of sexual orientation "a lesbian talks with her daughter", or alternative forms of belief systems: "feminist spirituality from witchcraft to herbal healing and yoga". In the "women in other countries series" the focus was on Boston and lesbian groups; the June issue was a special gay rights issue.

With the election of Margaret Thatcher, the magazine repeatedly voiced fears and concerns about her newly elected government and its impact on women's lives. It published a special issue on education in 1979, denounced conditions in the catering industry, the dangers of the pill, and reported on Unions' work and how far women have come. The May issue "you start by sinking into his arms and end up with your arms in his sink" showed that at the end of the decade, the power struggle between men and women was not over.

15 Most topics and debates were mirrors of their times and some quite surprising if not unsettling: child suicide for instance is something we still do not speak much about. The interview of a prostitute also seemed quite ahead of its time by giving a voice to a group of people usually defined by their body's usefulness to men. It first serves as what seems to be a call for more sexual freedom: "men will continue to need prostitutes so long as there is inhibition about sex" but in a way, reveals the opinion at 
the time that prostitution is in the end the women's fault as "wives are very often responsible" arguing that men turn to prostitutes because of their "domineering" spouses. The opinion was that of the prostitute and though it is surprising to read such a stance in a feminist magazine it also shows the determination of the editors to allow a woman express her thoughts as an individual and not silence her so she can fit in with the editorial line.

I have been able to give here only a glimpse of the riches of this archive, which one can hope will be thoroughly studied in years to come.

\section{NOTES}

1. Spare Rib p13 « Prostitution: for the love of money »

\section{AUTHOR}

\section{SHIRLEY DOULIÈRE}

Université de Bourgogne Franche Comté

Shirley Doulière is a PhD student at the university Bordeaux Montaigne and ATER at the university of Besançon. Her doctoral thesis is entitled: The Tightrope Walkers of Identity: Victorian Female Explorers Map out a New Atlas of Femininity. 